\title{
A FOTOGRAFIA HOMOERÓTICA AFRICANA DE FANI-KAYODE
}

Debora Armelin Ferreira

Resumo

Esta pesquisa busca analisar a produção artística do fotógrafo nigeriano Rotimi Fani-Kayode (1955-1989) que encontrou na fotografia um meio de expressar de forma sensível e transgressora a questão da homossexualidade, trazendo o seu próprio corpo nu como foco central das composições. Por meio da análise de duas de suas obras pretende-se compreender como a arte possibilita abrir caminhos para discussão sobre a questão de gênero nos tempos atuais, principalmente em países em que o número de mortes da população $\operatorname{LGBTI}+{ }^{1}$ ainda é alarmante.

Palavra-chave: Fotografia; Homossexualismo; Corpo; Nigéria.

\section{FANI-KAYODE AFRICAN HOMOEROTIC PHOTOGRAPHY}

\section{Abstract}

This research seeks to analyze the artistic production of the Nigerian photographer Rotimi Fani-Kayode (1955-1989) who found in photography a way to express in a sensitive and transgressive way the issue of homosexuality, bringing his own naked body as a central focus of the compositions. Through the analysis of two of his works, we intend to understand how art allows to open discussion about gender issue in the current times, particularly in countries where the death toll of the LGBTI+ population is still alarming.

Keyword: Photography; Homosexualism; Body; Nigeria.

\section{Introdução}

O tema homossexualidade persiste em ser um grande tabu ainda nos dias atuais em diversos países em que o resquício de colonialismo patriarcal atua de forma estrutural. Há que se debater essa questão em diversas vertentes com o objetivo de fazer com que a sociedade reflita quanto aos pré-conceitos de viés conservadores que habitam olhares, falas e ações possam ressurgir com novas e diferentes percepções.

Dentro do campo da História e Crítica da Arte, os questionamentos quanto ao dualismo sexo

1 A sigla LGBTQI+ representa Lésbicas, Gays, Bissexuais, Travestis, Transexuais, Intersexuais e as demais orientações sexuais, identidades e expressões de gênero. 
vs. gênero se faz presente na chamada Arte Contemporânea em que artistas trabalham esta temática a fim de se levar a discussão ao seu público.

O artista nigeriano Rotimi Fani-Kayode (1955-1989) escolheu a fotografia como uma forma de expressar a questão da homossexualidade e negritude, trazendo seu e outros corpos nus nas composições de suas obras explorando a sexualidade e a espiritualidade em suas imagens.

Neste artigo, partiremos, primeiramente, de um breve panorama das representações homossexuais dentro da História da Arte, desde à Arte Romana ao Modernismo, dando ênfase à linguagem da fotografia e o retrado do corpo nu masculino.

Em seguida, trataremos da questão LGBTI+ na Nigéria, suas relações políticas, culturais e sociais tentando compreender o que levou o país a figurar entre os primeiros na lista dos mais homofóbicos do mundo.

E por fim, conheceremos trajetória de vida e artística de Fani-Kayode através da leitura de suas obras, uma das muitas leituras possíveis que faremos visando um olhar de ativismo, embora o artista nunca tenha se autodeclarado como tal.

Esta pesquisa pretende contribuir para a discussão e reflexão da temática LGBTI+ no meio acadêmico e fora dele, sendo a arte um campo potente de diálogo, possibilitando que seus espectadores possam romper velhos paradigmas.

\section{Representações homossexuais nas Artes}

O território do campo do conhecimento como o das artes também apresenta características hegemônicas legitimadas por instituições que seguem um pensamento eurocêntrico e que acarretou (e ainda acarreta) exclusões de determinados grupos durante toda História da Arte. Há a necessidade de descentralizar pensamentos hierárquicos no objetivo de decolonizar o olhar, romper com velhos discursos normativos a partir de novas narrativas nas produções artísticas contemporâneas.

Ao analisarmos obra de artes desde o Renascimento à modernidade no que se refere às representações de sexualidade e gênero vemos quase que exclusivamente homens brancos se relacionando, uma vez que na Grécia e Roma Antiga, essas relações eram aceitas desde que entre homens jovens.

Como observamos o fragmento de um cálice de metal (Fig. 1) em que um homem está 
sentado no colo de outro. Apesar dos romanos terem absorvido um pouco da cultura grega, as relações entre homens erma estabelecidas sempre através do poder e apenas para satisfação sexual.

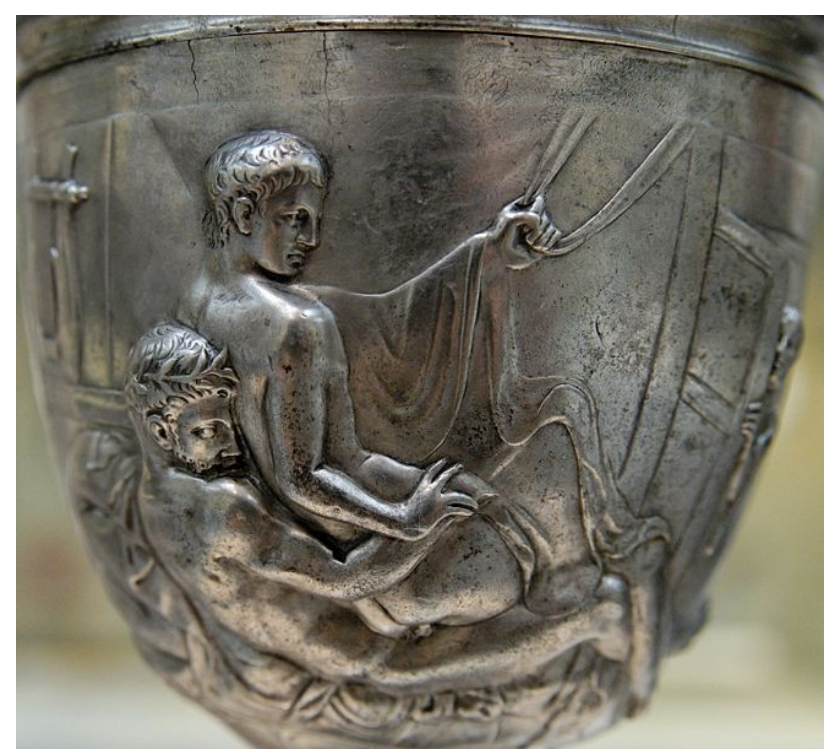

Figura 1. Detalhe de cálice de metal, séc. VIII - IV.

Disponível em:https://esqrever.com/2016/10/10/a-homossexualidade-nos-classicos-ena-modernidade

No detalhe do teto da Capela Sistina, uma obra renascentista pintada por Michelangelo entre os anos de 1508 e 1512 (Fig. 2), se observa uma cena de homens se beijando o que representa, no contexto do Juízo Final, o beijo gay no lugar do pecado condenável, o pecado da sodomia

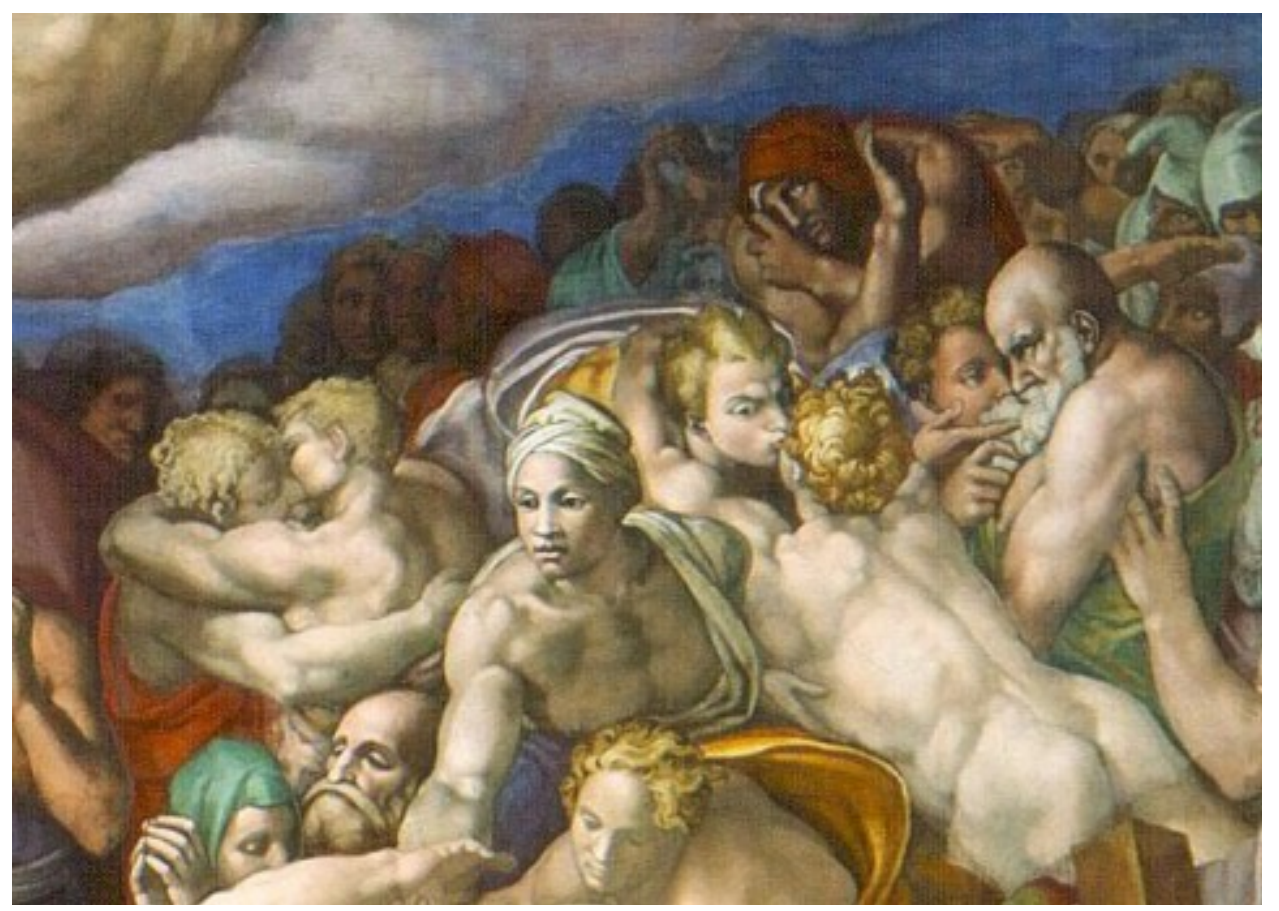

Figura 2. Capela Sistina, pintura afresco (1508-1512) de Michelangelo, 
Palácio Apostólico, Vaticano

Imagem registada em Huffpost, disponível em : https://www.huffpostbrasil.com/2017/ 09/13/9-obras-de-arte-consagradas-da-historia-que-retratam-genero-esexualidade_a_23208027l

Gustav Coubet (1818-1877), em 1866, que de um modo natural retratou um casal de mulheres nuas, em uma cama, trocando caricias. O corpo nu feminino sempre foi objeto de representações na Historia da Arte, mas a cena de duas mulheres causou indignação na época uma vez que relações entre mulheres não eram aceitas.

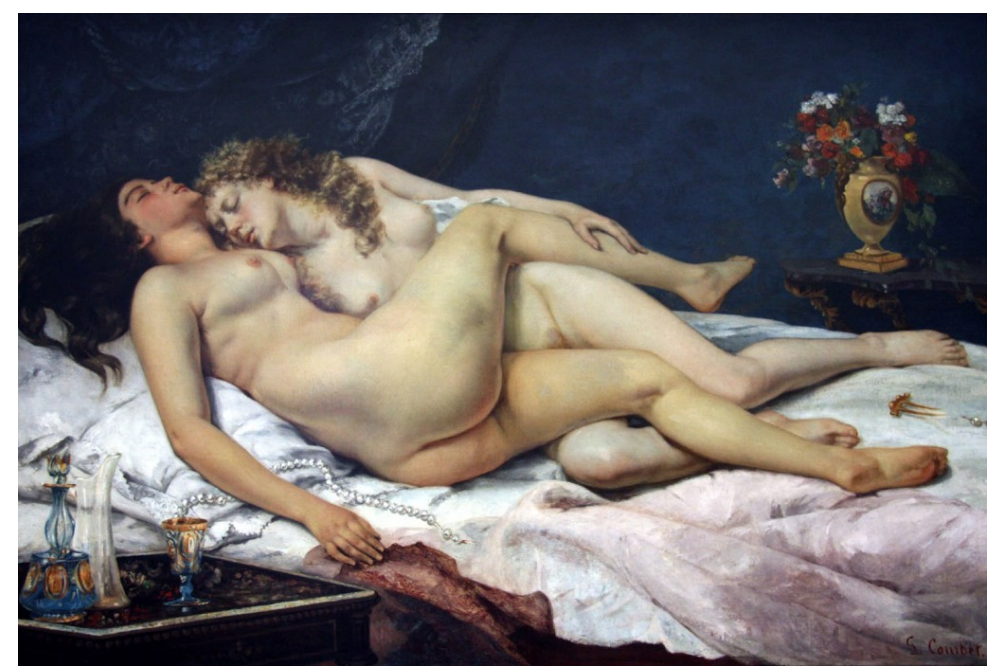

Figura 3: Gustav Coubert, Le Sommeil, 1866.

Disponível em: http://warburg.chaa-unicamp.com.br/obras/view/774

Na linguagem da fotografia, damos enfoque ao corpo nu masculino que, à princípio, não foi categorizado como uma fotografia artística porque críticos acreditavam que estas só interessavam ao público gay.

O precursor foi o fotógrafo alemão Wilhelm von Gloeden (1856 - 1931) que entre o final do século XIX e início do XX, retratou corpos masculinos como na imagem Youths in Grotto (Fig. 4) em que fotografou dois jovens nus em uma gruta da Itália deixando implícito uma relação mais intima entre eles. 


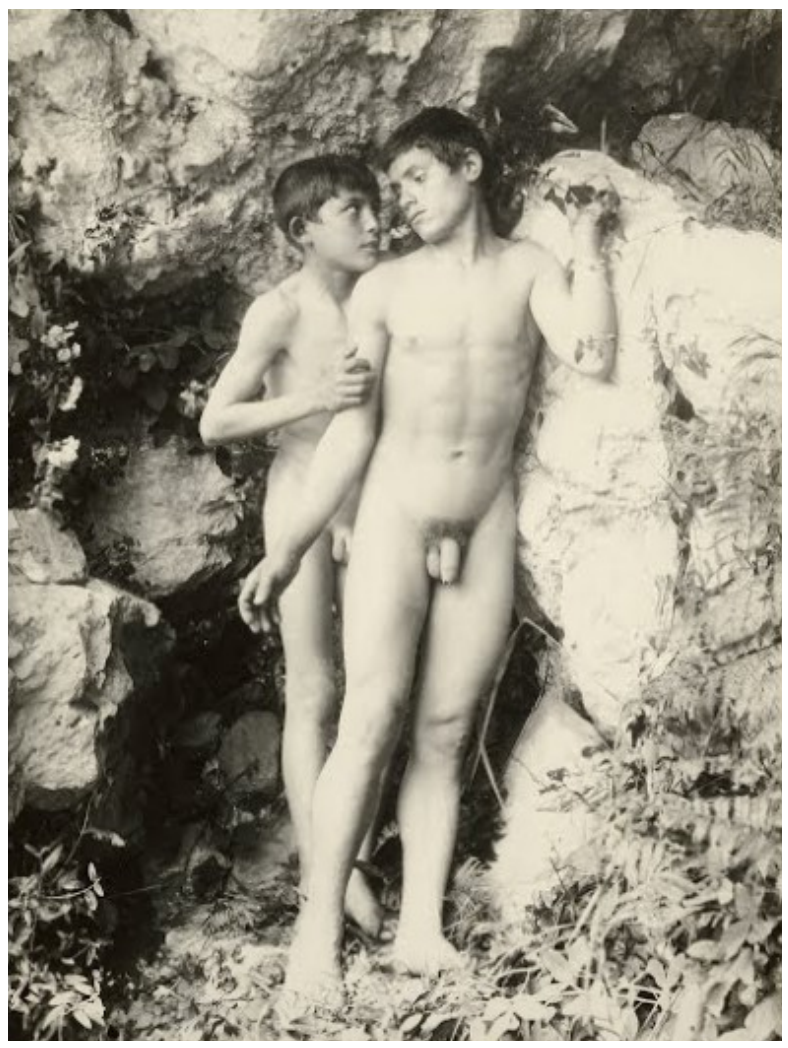

Figura 4. Baron Wilhelm von Gloeden, Youths in Grotto, 1885 - 1905.

Museu J. Paul Getty, disponível em:

http://www.getty.edu/art/collection/objects/40992/baron-wilhelm-von-gloeden-youths-ingrotto-german-about-1885-1905/

Assim como o fotógrafo norte-americano F. Day Holland (1864 - 1933) que tinha como foco de interesse em sua câmera fotográfica, corpos masculinos geralmente nus (Fig. 5) repleto de simbolismo relacionado à religião e mitologia. 


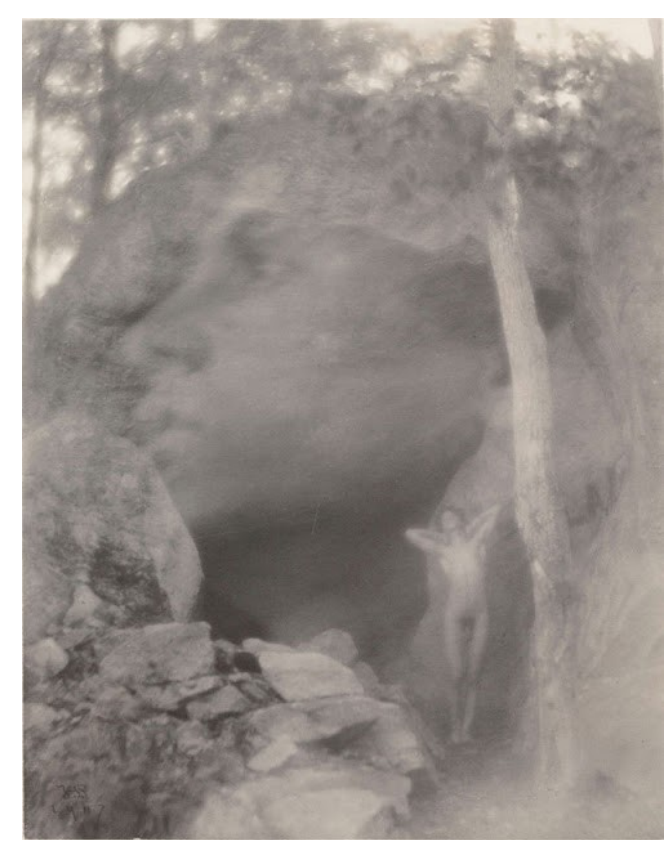

Figura 5. F. Day Holland, La vision (scène d'Orphée), 1907.

Metropolitan Museum, disponível

emhttps://www.metmuseum.org/art/collection/search/294823

A fotografia de Robert Mapplethorpe (1946-1989) foi quem conseguiu o status de arte por ter atingido reconhecimento da crítica internacional com registros do cenário homossexual norteamericano durante as décadas de 1970-80, apresentando não somente o corpo nu (Fig. 6), mas fotos eróticas e do universo sadomasoquista com que fazia de uma forma muito sensível, estilizando suas composições com o uso de diferentes técnicas.

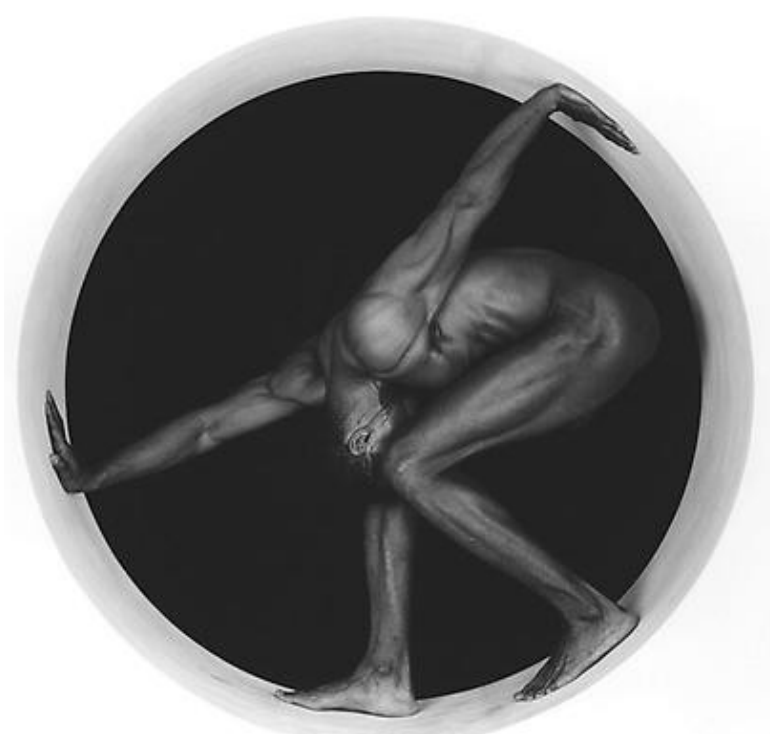

Figura 6. Robert Mapplethorpe, Thomas, 1987.

Disponível em: http://www.mapplethorpe.org/portfolios/male-nudes/ 
E foi de Mapplethorpe que veio a influência das fotografias de Rotimi, de corpos nus com contraste com o fundo neutro e suas composições, porém em Mapplethorpe, o corpo negro nu assume um lugar de objeto de desejo, fetiche e sexualidade enquanto em Rotimi, a abordagem transita no local da imaginação, entre a espiritualidade e a sexualidade.

\section{A questão LGBT na Nigéria}

O tema da homossexualidade é um tabu em diversos países e na Nigéria não é diferente, sendo que, de acordo com uma pesquisa feita pela Pew Research ${ }^{2}$ (quadro 01) é considerado um dos países mais homofóbicos do mundo. Neste item do artigo tentaremos compreender quais as causas que levaram o país a apresentar manifestações preconceituosas e de perseguições a pessoas LGBTI+ e uma lei anti-gay.

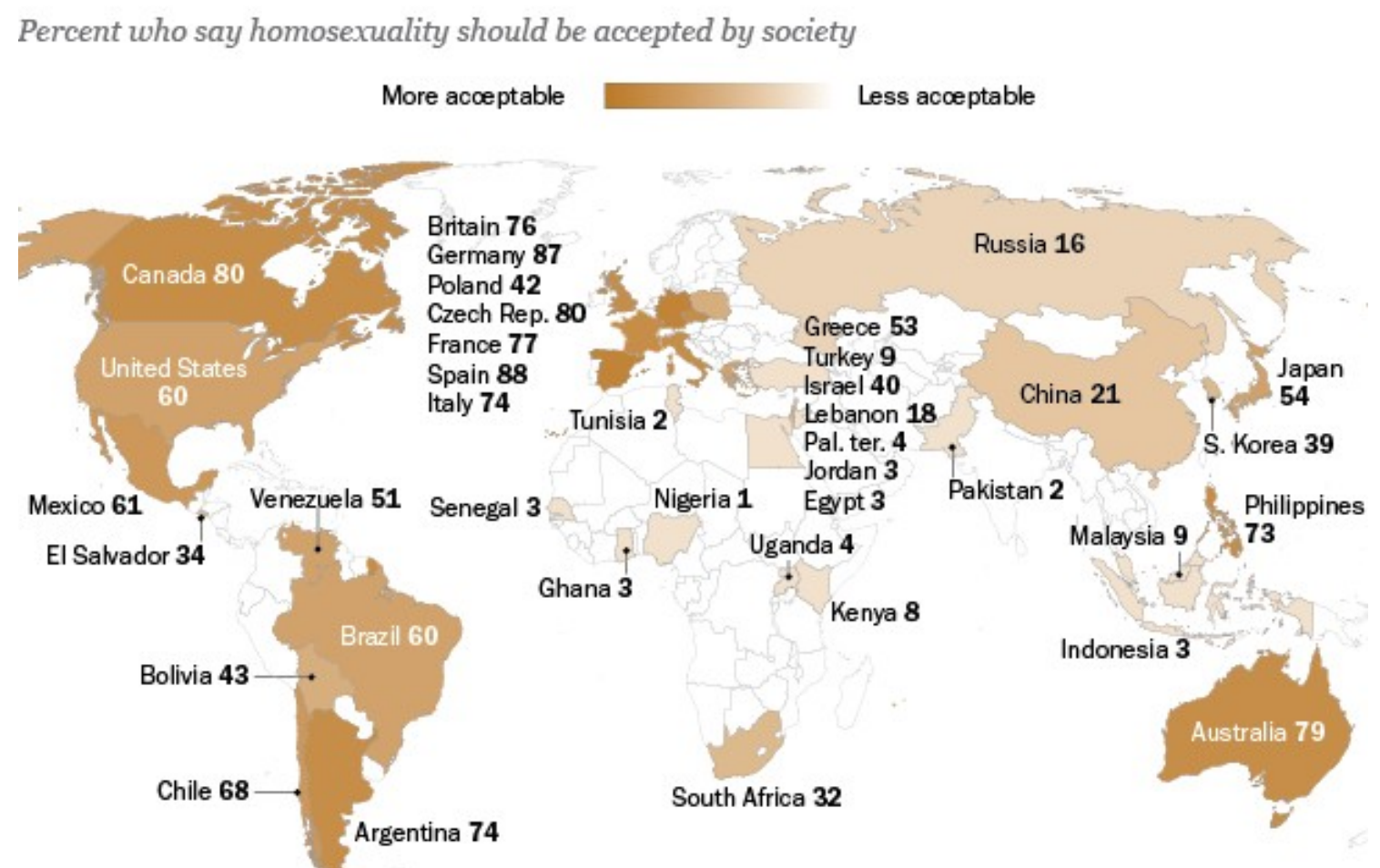

PEW RESEARCH CENTER

Quadro 01: PEW RESEARCH CENTER, Global Acceptance of Homosexuality. Fonte: http://www.pewglobal.org/2013/06/04/global-acceptance-of-homosexuality $L$

2 PEW RESEARCH CENTER, Global Acceptance of Homosexuality. Disponível em: http://www.pewglobal.org/2013/06/04/global-acceptance-of-homosexuality/. Acesso em: 28/12/2016 
Quando a Nigéria ainda era um protetorado britânico (e em alguns anos do pósindependência), vigorou um modelo punitivo e hostil conhecido como Código Penal Britânico que tinha como punição a pena de morte como consequência de algumas infrações.

Este caráter agressivamente homofóbico da população se tornou mais forte após a lei antigay, de 2014, ser sancionada fazendo com que a forte negação da existência de homossexuais anterior se tornasse como um ato ilegal e essa reação é vista com mais dureza em áreas rurais do país.

Anterior a 2014, houve outra tentativa de se aplicar leis contra pessoas homossexuais, mas esta foi sancionada somente pelo então presidente Goodluck Jonathan conhecida como Same-sex Marriage (Prohibition) Act que tem como cláusulas a proibição do casamento ou união civil por pessoas do mesmo sexo com 14 anos de prisão; registros de sociedades, organizações e clubes homossexuais, assim como manifestação de afeto em público por pessoas do mesmo sexo com pena de 10 anos de prisão; e, inclusive, quem testemunhar, apoiar ou ajudar a realização de cerimônias de casamento ou registro de organizações e sociedades homossexuais, pena de 10 anos de prisão.

No caso da região norte, que é dominada pela Sharia, código islâmico presente em 12 estados, pune duramente a homossexualidade com apedrejamento até a morte pois é considerado como uma ofensa capital, apesar de que não haver registros de que alguém que tenha sofrido essa pena.

Para Jark (2015), esse comportamento se relaciona a uma tentativa de descolonização, uma forma de confrontar o imperialismo cultural ocidental, como aponta,

(...) levando em conta o passado colonial da Nigéria e suas características de colonialidade, assume-se a visão de que o comportamento homofóbico presente em setores estatais nigerianos seria um esforço "desocidentalizante", ou seja, uma forma de enaltecer as percepções locais da sexualidade em sua conduta contemporânea para com os LGBT” (JARK, 2015, p. 14)

Percebemos que este argumento tem apoio religioso tanto da região do norte, predominantemente islâmica, quanto da região sul, cristã, que consideram a homossexualidade como uma criação contra a natureza, que não faz parte da herança africana (como se o islamismo e o cristianismo fossem “naturalmente” africanos) e atinge seus preceitos morais.

Há um grande número de nigerianos que condenam os homossexuais tanto que o apoio a lei é grande e muitos civis e policiais perseguem e ameaçam pessoas nas ruas. Como consequência, 
muitos não assumem sua sexualidade ou então, após ameaças, pedem asilos em outros países. Uma forma que muitos têm encontrado é a rede social, um canal no qual podem conversar, trocar informações e até promover encontros. Ifekandu (2014) relata que a internet se tornou um espaço seguro em que as pessoas LGBTI+ tem vozes e podem se organizar, uma vez que não há controle e nem censura do governo na internet.

Há que se quebrar velhos paradigmas impostos pela sociedade no que se refere a dicotomia sexo vs. gênero e da estabilidade binária do sexo como somente feminino e masculino. Butler (2016) sugere não pensarmos que a

“(...) construção de "homens” se aplique exclusivamente a corpo masculinos, ou que o termo "mulheres" interprete somente corpos femininos. Além disso, mesmo que os sexos pareçam não problematicamente binários em sua morfologia e constituição, não há razão para supor que os gêneros também devam permanecer em número de dois.” (BUTLER, 2016, p.26)

Apesar do panorama nigeriano ainda seja negativo, há tentativas de se levantar discussões sobre sexualidade e gênero através do cinema, tendo Nollywood, a indústria cinematográfica popular, que, desde 2003, apresentou ao menos 25 filmes com personagens que mantinham relações com pessoas do mesmo sexo (GREEN-SIMMS, 2016). Como na literatura, escritores como Chimamanda Adichie, Jude Dibia e Chris Abani relatam em suas histórias personagens homossexuais.

Em dezembro de 2019, 47 homens foram à julgamento por terem demonstrado afetos por pessoa do mesmo sexo em locais públicos. Não houve condenação, portanto, Xeenarh Mohammed, diretor executivo da TIERS $^{3}$ de Lagos, acredita que a lei é utilizada apenas com o intuito de assediar e chantagear os homossexuais nigerianos.

\section{Rotimi Fani-Kayode: Fotografia negra, africana e homossexual}

"Portanto, é a fotografia - fotografia negra, africana e homossexual - que devo usar não apenas como instrumento, mas como arma para resistir a ataques à minha integridade e, de fato, à minha existência nos meus próprios termos”.

(FANI-KAYODE \& HIRST, 1996 - tradução livre)

3 TIERS: The Initiative for Equal Rights 
A vida pessoal de Oliwarotimi (Rotimi) Adebiyi Wahab Fani-Kayode (fig. 7) é fortemente refletida em sua trajetória artística. Nascido em Lagos, Nigéria, no ano de 1955, filho de Babaremilekun Adetokunboh Fani-Kayode, político e aristocrata, e da Sra. Adia Adunni FaniKayode, a família se exila na Inglaterra no ano de 1966, ano do golpe militar em seu país e subsequente guerra civil que dividiu o país em três regiões principais de acordo os grupos étnicos: Haussa (Norte), Igbo (Sudeste) e Iorubá (Sudoeste) e deixou o país assolado com milhares de mortes.

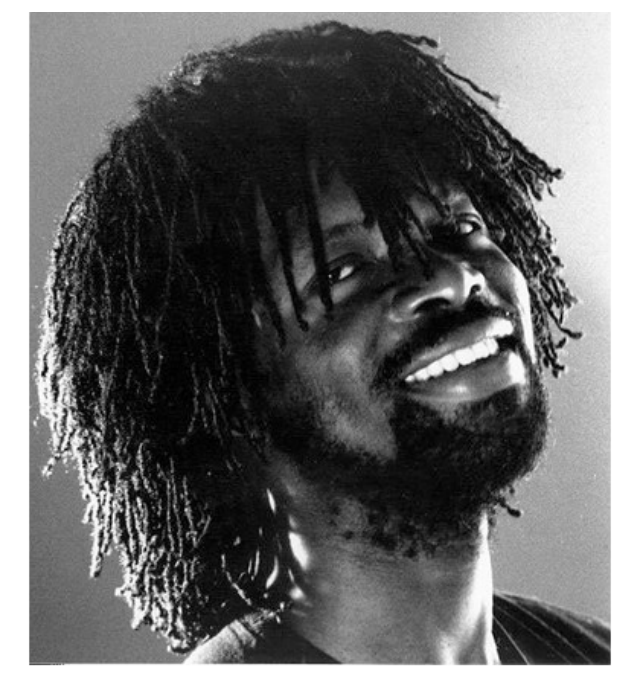

Figura 7. Foto de Rotimi Fani-Kayode, disponível

em:HTTP://blackcontemporaryart.tumblr.com/post/23038818587/dynamicafrica-rotimi-fanikayode-was-born-in

Por ter estudado em escola cristã britânica, Rotimi não teve problemas em dar prosseguimento aos seus estudos na Inglaterra. Porém, aos 21 anos, em 1976, muda-se para os Estados Unidos onde se gradua em Belas Artes e em Economia (apenas para agradar seus pais) pela Georgetown University, em Washington e posteriormente, conclui o mestrado em Belas Artes e Fotografia pelo Instituto Pratt de Nova Iorque.

Neste período conhece Mapplethorpe que influenciou muito no seu trabalho. Assim, simultaneamente, o movimento gay ganhava forças nos Estados Unidos entre as décadas de 1970 e 80 dando início à discussão dentro da sociedade sobre a questão.

Rotimi retornou a Inglaterra em 1983 quando conheceu Alex Hirst (1951- 1992), e iniciam uma parceria pessoal e profissional bastante criativa. Essa parceria dura até 1989, quando o artista estava em tratamento contra o HIV e sofreu uma parada cardíaca fulminante. Uma trajetória curta e 
marcante, fecunda e inovadora e que permanece forte como referência na luta LGBT.

Em sua trajetória, o artista escolheu a fotografia como meio de expressão, uma ferramenta política para falar de forma crítica sobre questões como a sexualidade, espiritualidade, identidade e diáspora. Suas fotografias apresentam uma forma dramática e serena ao retratar a si mesmo e a outros homens negros e nus explorando noções de masculinidade e homoerotismo, envolvendo um mistura sofisticada e até mesmo ambígua da iconografia africana e ocidental. Para ele a fotografia era não somente uma ferramenta, mas uma arma, como em suas próprias palavras,

"Por essa razão, eu sinto que é essencial resistir a todos ataques que desencorajam a expressão da identidade de alguém. No meu caso, minha identidade tem sido construída do meu próprio senso de alteridade, seja cultural, racial ou sexual. Os três aspectos não estão separados dentro de mim.” (FANI-KAYODE \& HIRST, 1996 - tradução livre)

O fotografo se considerava um “estranho” tanto referente à sua sexualidade quanto à questão de deslocamento geográfico e cultural devido à sua situação diaspórica: em 20 anos, viveu em três continentes, África, Europa e América do Norte.

O corpo nu foi sempre o foco central de suas composições, encenadas com fundos neutros em que foi possível explorar o corpo com muita originalidade e sensibilidade. Este corpo ressalta a importância da linguagem corporal na criação e produção material e imaterial em alguns grupos étnicos africanos, sendo este um veículo de conexão entre o mundo visível e invisível durante os rituais e cerimônias.

A investigação fotográfica em que são trazidas as memórias ancestrais e simbolismos da cultura Iorubá, representados em narrativas construídas através de composições que abarcam poses gestuais e rituais buscando retratar uma dimensão espiritual se reapropriando de tais objetos na construção de novas imagens e novos significados.

A religião africana, para o fotógrafo, habitava no campo da memória e por ter saído muito cedo de sua terra natal, o contato não chegou a ser profundo. Teve, então, que pesquisar sobre a história e a civilização Iorubá, de onde pertencia sua família, para que levasse a dimensão espiritual em seus trabalhos.

No caso da obra Bronze Head (Fig. 8), de 1987, uma fotografia em preto e branco onde é feito o recorte de um corpo, registrando apenas da cintura para baixo: nádegas e fragmentos das pernas, sentado sobre uma cabeça de bronze Ifê que está apoiada em um banco, sob um fundo escuro e uma luz direta lançada sobre o corpo e a cabeça. O corpo fragmentado sobre esta peça da 
arte tradicional africana ${ }^{4}$ permite uma leitura que quebra concepções/construções quanto ao passado e seus simbolismos e sua força.

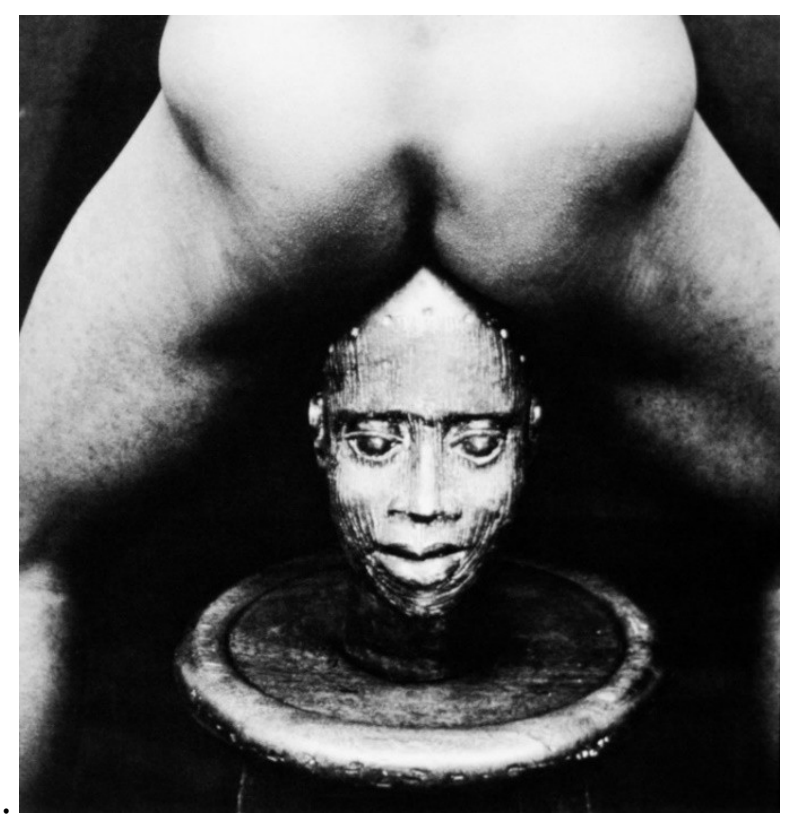

Figura 8. FANI-KAYODE, Rotimi. Bronze Head, 1987. Disponível em: Fani-Kayode, 1996.

O artista possibilita uma relação entre a religião Iorubá, através de sua iconografia, no caso, a cabeça Ifê, ressignificando-a através do homoerotismo como uma possibilidade de transformação, uma conexão passado x contemporâneo.

Hirst comenta sobre Bronze Head,

“(...) Rotimi está "dando à luz" a um bronze de Ife. Ife, o berço de uma cultura Iorubá, que é também sua cidade de origem. Seu pai é um Balogun de Ife e sua família tem o título tradicional de Akire, guardiães do santuário de Ifa, o oráculo. A cabeça, ori, que para o ioruba é a sede do espírito, o orisha, representa um deus. Simbolicamente, o artista está transformando sua antiga cultura em termos contemporâneos, tendo compreendido que os antigos valores já não "funcionam", mas ainda têm poder como arquétipos. Além disso, ele está apresentando seu traseiro, uma afronta tradicional para os poderes. A imagem contém a ideia da cabeça como um "falo superior", penetrando e fecundando o artista. Apesar de ser um homem, destinado a penetrar as profundezas do inconsciente, o artista é também um "receptor" feminino que é fecundado por ele e assim capaz de produzir o "filho" de Deus." (HIRST apud NELSON, 2005, p.10 - tradução livre)

Como Hirst sugere a ideia do corpo dando à luz a máscara, podemos também pensar na

4 De acordo com Salum (1999, para. 27), entende-se por arte tradicional africana, “um reducionismo inventado por estrangeiros, mas que está cristalizada entre nós, relativa a toda produção material estética da África produzida antes e durante a colonização, até meados do século XX”. 
máscara penetrando este corpo, o simbolismo religioso que este objeto carrega volta a fazer parte de si, adentrando o seu ser a fim de compor a sua identidade. Algo que sempre se revelou presente em sua ancestralidade, mas que houve distanciamento devido à partida de seu local de origem.

Já em Sonponnoi, 1987 (Fig. 9), Rotimi apresenta uma imagem em preto e branco, com fundo escuro, preto, um corpo pintado com bolas brancas e pretas com o rosto e pernas cortadas a partir do joelho para baixo, vestindo dois colares enquanto segura um copo com três velas acesas. Sonponnoi, em Iorubá, é o orixá da varíola, temido porque é uma manifestação da ira de Olorun, puniu seus infratores com a doença da varíola. O temor da população é tamanha que muitos receiam até seu pronunciar seu nome.

Aqui, o fotografo faz referencia ao orixá Sonponnoi, evocando a essa divindade a partir das manchas que faz referência à varíola que causa erupções na pele. É como se criasse um ritual de passagem ou uma cerimônia a partir das velas acesas que esconde a genitália de um corpo sem cabeça, mantendo seu anonimato.

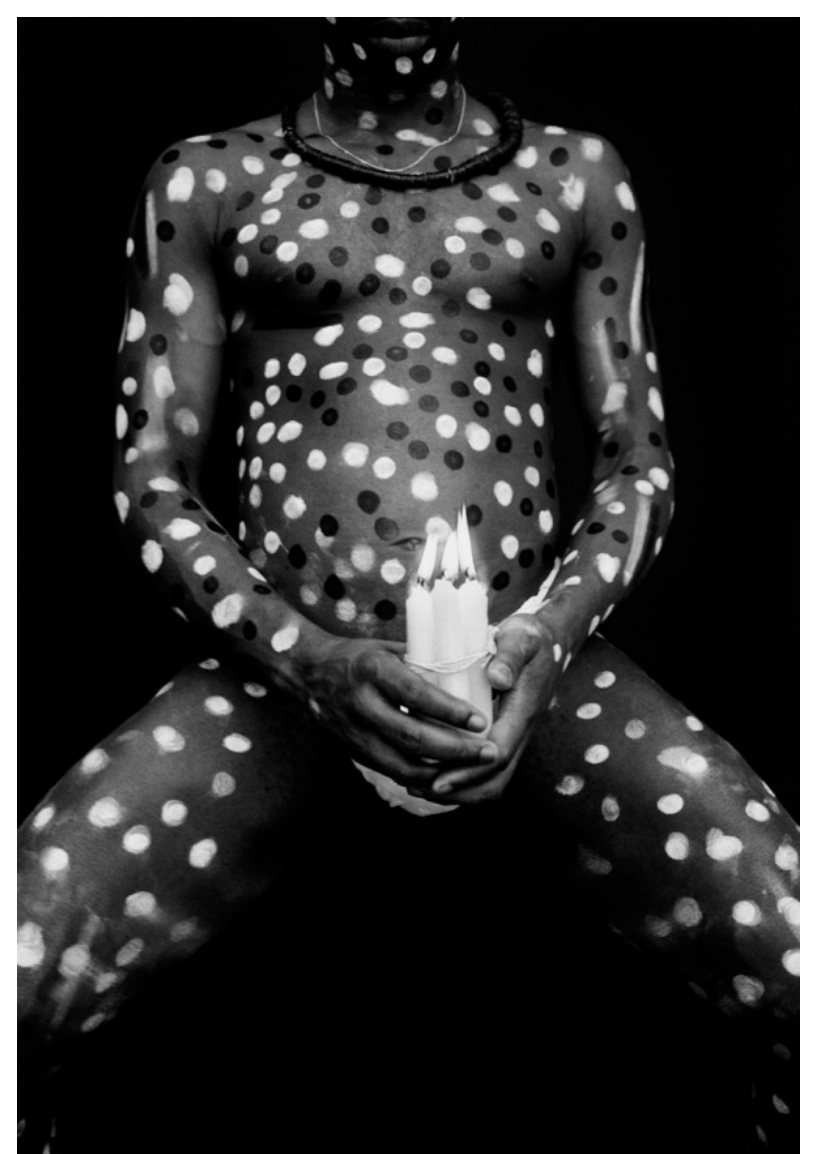

Figura 9. Rotimi Fani-Kayode, Sonponnoi, 1987. Autograph ABP \& Tiwani Contemporary, disponível em:https://writinginrelation.wordpress.com/2014/10/06/rotimi-fanikayode-1955-1989-traces-of-ecstacy/ 
Busca manter essa relação entre o mundo espiritual mantendo a iconografia Iorubá, mas permitindo apresentar conceitos amplos que permitam ao espectador ter diferentes leituras e interpretações de suas obras. Assim ele comenta,

\footnotetext{
"Às vezes eu acho que se eu levasse o meu trabalho para as áreas rurais, onde a vida ainda está vigorosamente em contato com ela mesma e com suas raízes, a recepção pode ser mais construtiva. Talvez se eles reconhecessem meus Deuses da varíola, meus sacerdotes transexuais, minhas imagens de homens negros desejáveis em um estado de frenesi sexual, ou a tranquilidade de comunhão com o mundo espiritual, talvez eles tenham menos medo de se deparar com o mais escuro dos segredos sombrios da África, pelo qual alguns de nós procuram para ter acesso à alma."
}

Enquanto o homoerotismo foi um meio usado para se aproximar de uma transformação, uma forma de transgressão no intuito de desprender a mente do corpo, como na obra The Golden Phallus, 1989 (Fig. 10). Nesta fotografia colorida, um corpo negro apoiado em um banco veste uma máscara branca em seu rosto enquanto seu pênis dourado é erguido por um fio branco sob um fundo que varia de um tom de marrom e este corpo é iluminado por um feixe suave de luz.

Aqui não podemos deixar de entender a ideia do artista de um corpo politizado, trazendo uma relação entre mente e corpo que é sinalizada pela própria transcendência: uso da máscara que encobre a identidade do personagem fotografado, assim como a manipulação do pênis. 


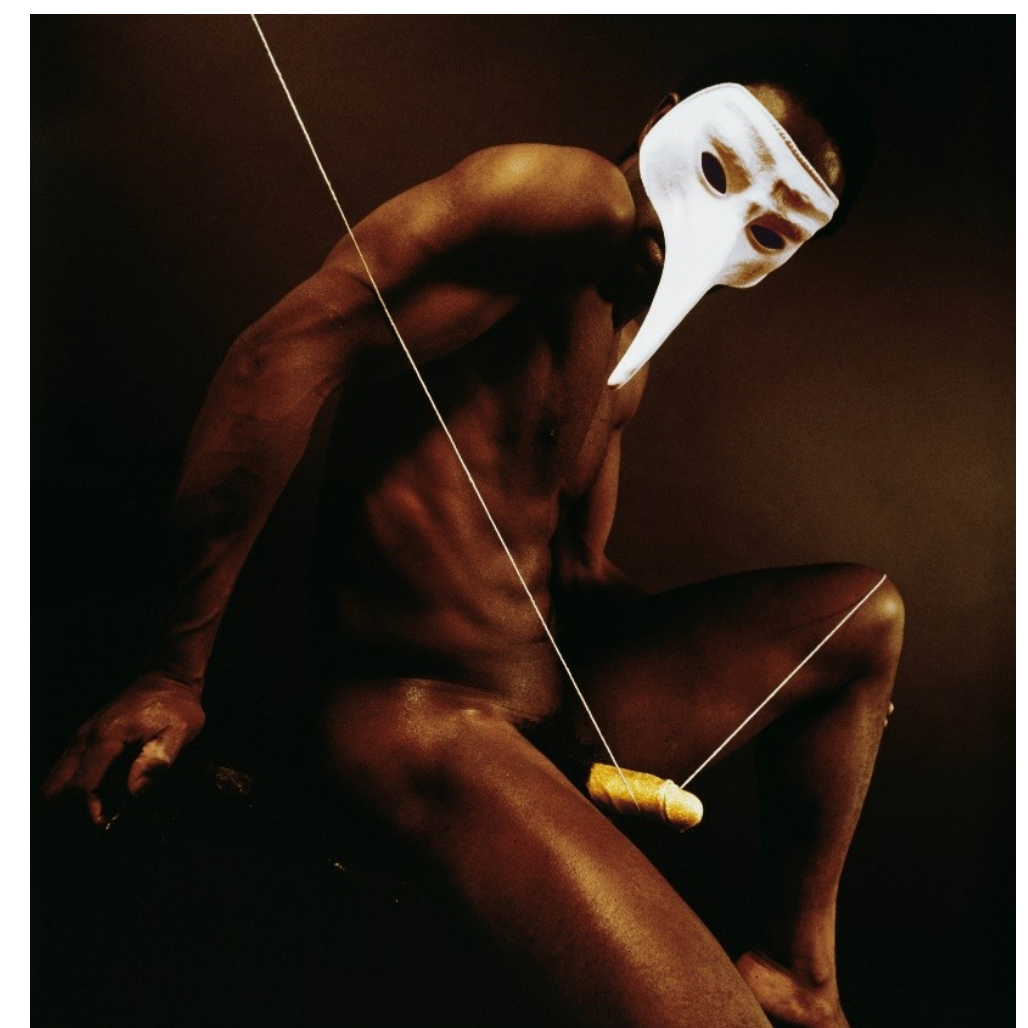

Figura 10. FANI-KAYODE, Rotimi. The Golden Phallus, 1989.

Disponível em: FANI-KAYODE, 1996.

E ainda, sob a ótica colonizadora, há mais uma leitura possível, remetendo ao espectador questões que permeiam o imaginário pós-colonial do erotismo: o corpo masculino negro fetichizado, visto como objeto de desejo, a objetificação de um corpo forjado através dos processos coloniais, situando o olho do observador como fonte de desejo.

Em Every Moments Counts II, 1989 (Fig. 11), um corpo negro de costas, aparentemente ajoelhado e com os cotovelos apoiados sobre um móvel, segura uma máscara (a mesma usada em Golden Phallus), enquanto que uma mão agarra suas nádegas. Nesta leitura, podemos pensar quanto a sua identidade como africano, homossexual e negro é intrínseca. Ao mesmo tempo em há uma busca por sua ancestralidade através da religiosidade ao registrar a máscara iorubá, sua sensualidade e sexualidade se manter presente com a intenção de romper os tabus criados pela sociedade. Traz essa tensão entre espiritualidade e sexualidade necessário para demonstrar, talvez, um novo homem ancestral, uma forma moderno de representação. 


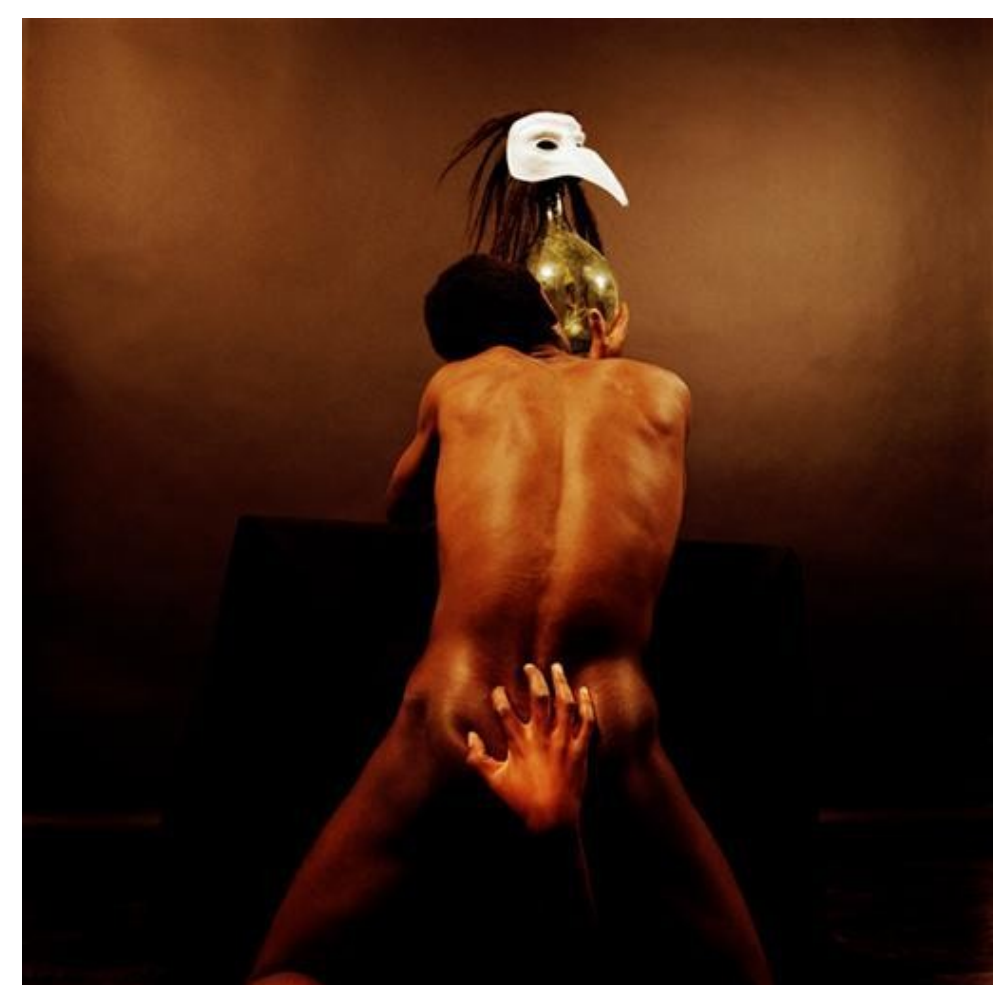

Figura 11. FANI -KAYODE, Every Moment Counts II, 1989. Disponível em: FANI-KAYODE, 1996.

Seus trabalhos não são apenas baseados na construção identitária de Fani-Kayode, mas tem o propósito de questionar a própria capacidade do corpo em se manter numa posição como expressão própria de identidade e experiência. Este corpo que vive, sente e se expressa.

Na parceria com Alan Hirst, exploraram juntos a multiplicidade de identidades como a de homossexual e a negritude criando um local de discurso sobre uma sociedade racista e homofóbica, traduzindo suas raivas e questionamento em imagens que tem o intuito de provocar seus espectadores que carregam percepções convencionais e conservadoras.

Em 1988, o artista fez história ao fundar a Associação de Fotógrafos de Preto em Londres, a Autograph $\mathrm{ABP}^{5}$, que tem a missão de defender a inclusão de práticas fotográficas historicamente marginalizadas. A instituição de caridade trabalha, até os dias atuais, com fotografia, identidade cultural, raça, representação e os direitos humanos em todo o mundo.

\section{Considerações Finais}

Para Rotimi Fani-Kayode, a diáspora possibilitou desenvolver o senso de alteridade nos aspectos que tange a questão racial e sexual. Ele se sentia um "estranho” e isso fez que pudesse

5 Para mais informações sobre a Associação de Fotógrafos de Preto acessar o site: http://autograph-abp.co.uk/ 
vivenciar um senso de liberdade, possibilitando experimentações em sua carreira artística.

A arte serviu como uma ferramenta de combate ao racismo e principalmente à homofobia, a qual foi sua luta durante toda a vida. Ele foi sensível e ao mesmo tempo corajoso e transgressor ao expressar sua identidade através da fotografia homoerótica, contrariando todo o discurso de uma sociedade conservadora que ignora que as relações homossexuais e eróticas que sempre existiram na história da humanidade.

Um modo subversivo em que o fotógrafo também encontrou para tratar a questão da relação de poder racial associado ao neo-colonialismo, envolvendo uma investigação mais poética sobre a negritude, masculinidade e sexualidade.

Rotimi chegou a cogitar uma exposição em Lagos, mas temia um possível protesto na capital nigeriana e que fosse acusado de ser um provedor de valores ocidentais decadentes e corruptos.

É preciso fazer com que a homossexualidade seja discutida num âmbito social, político e cultural em todos os cantos do mundo, dentro e fora da academia, compreendendo se tratar de algo que é inato, que faz parte do indivíduo desde o seu nascimento, se manifestando ao longo da vida, cada um a seu tempo dependendo do ambiente em seu entorno, aceitações de familiares e amigos, e sua própria conscientização sexual e autoconhecimento.

Rotimi esteve à frente de seu tempo, não se autointitulou como ativista, mas suas obras refletem, até os dias atuais, uma luta que vai além das esferas artísticas. É necessário libertar-se da prisão imposta por velhos paradigmas e buscar, onde quer que seja, uma forma de expressão. E a arte é uma forte ferramenta na possibilidade de se fazer refletir e de combater pré-conceitos.

Temos visto, em um contexto dentro da arte contemporânea, o conceito de “Artivismo”, que se trata de ações de forte cunho político e social inseridos no território da arte. E dessa forma, podemos entender as manifestações artísticas como um veículo potente de combate ao preconceito contra pessoas LGBTI+, numa luta por discussões em espaços que deveriam ser mais democráticos em todos os âmbitos como museus, galerias e centro culturais, e sendo legitimado quando inserido nas academias. 


\section{Referência Bibliográfica}

BUTLER, Judith. (2016) Problemas de Gênero: feminismo e subversão da identidade. $11^{\circ}$ ed. Rio de Janeiro: Civilização Brasileira.

EPPRECHT, Marc. (dez./2009) Sexuality, Africa, History. The American Historical Review, vol. 114, n.5, p. 1258-1272.

FALOCA, Toyin and HEATON, Matthew M. (2008) A History of Nigeria. New York: Cambrigde University Press.

FANI-KAYODE, Rotimi \& HIRST, Alex. (1996) Photographs. Revue Noire Ed.

GREEN-SIMMS, Lindsey. The Emergent Queer Homosexuality and Nigeria Fiction in the 21st. Century. Research in African Literatures, vol. 47, n.2, p. 139-161.

IFEKANDU, Chiedu Chike. (2015) The fallout of Nigeria's anti-gay law and opportunities for the future for LGBTI persons and communities. In: Boldly Queer: African Perspectives on same-sex sexuality and gender diversity. Kenya: Black Butterfly Limited, p. 81-87.

JARK, Renan Batista. (2015) África e a colonialidade do ser: um estudo sobre os direitos LGBT na Nigéria. Monografia apresentada ao curso de Relações Internacionais da Universidade de Santa Catarina. Brasil: Florianópolis.

METZ, Helen Chapin. (1992) Nigeria: a country study. $5^{\circ}$ ed. Estados Unidos: Federal Research Division, Library of Congress.

NELSON, Steven. (2005) Transgressive Transcendence in Photographs of Rotimi Fani-Kayode. Art Journal, vol. 64, n. 1, p. 4-19.

SOGUNRO, Ayo. (2014) One more nation bound in freedom. Transition, n.14, Gay Nigeria, p. 4759.

TWORTON, Michael e WILSON-TAGOE, Nana (2004) National Health: Gender, Sexuality and Health in a Cross-Cultural Context. London: UCL Press.

\section{Website}

FERREIRA, Debora Armelin. Fani-Kayode: Sensibilidade e Transgressão na Fotografia Homoerótica Africana. Disponível em: http://www.afreaka.com.br/notas/fani-kayodesensibilidade-e-transgressao-na-fotografia-homoerotica-africana/ Acesso em: 13 de outubro de 2019.

A arte como arma em território hostil: Enfrentamentos nas produções de Lyz 
Parayo. $\quad$ Cidades [Online], $39 \mid 2019, \quad$ disponível em: http://journals.openedition.org/cidades/1399 Acesso em: 20 de janeiro de 2020.

SALUM, Marta Heloísa Leuba. (1999) África: culturas e sociedade. Da série Formas de Humanidade, Museu de Arqueologia e Etnologia da Universidade de São Paulo (USP), São Paulo. Disponível em: http://www.arteafricana.usp.br/codigos/textos didaticos/002/africa culturas e sociedades.html Acesso em: 13 de outubro de 2019. 